\title{
La persistencia del deseo Cintia Clara Romero La acción constructiva del discurso
}

Muestra de video realizada en el MAC-UNL en noviembre de $20 I I$

Stella Arber

Museo de Arte Contemporáneo

Universidad Nacional del Litoral

mac@unl.edu.ar

El proceso de ejecución del videoarte se sustenta en la producción y en la posibilidad de establecer una dinámica, tanto óptica como conceptual, a través de la narración fílmica y se transforma, a través de la materialización de la imagen en pantalla, en un relato audiovisual.

El soporte de ejecución utilizado, ofrece variadas posibilidades, en el caso de la instalación sonora-visual realizada por Cintia Romero, donde se podrán ver varias pantallas en todo el ámbito del museo, así se demuestra. Está planteada desde grabaciones de acción previa, resultante del exhaustivo trabajo de la artista, con su intervención directa sobre las programadas performances registradas, en el momento en que se produce la actuación, conciente de la función lúdica de las acciones, realiza una apropiación del relato, con total intensión en el momento de resolver la operación constructiva de su discurso.

Con una dinámica en tiempo real, con cámara fija generalmente, nos define a su vez un recorrido (espacio), entendido como período de acción (tiempo) y así surge la idea de recuperación permanente de la imagen transmitida.

Los monitores reconstruyen una y otra vez, el momento en que las imágenes fueron tomadas, en que las escenas se produjeron, y los registros fueron actuados, luego, todos a la vez, juntos en la otra escena, la escena de la instalación museística, toda realidad individual se 

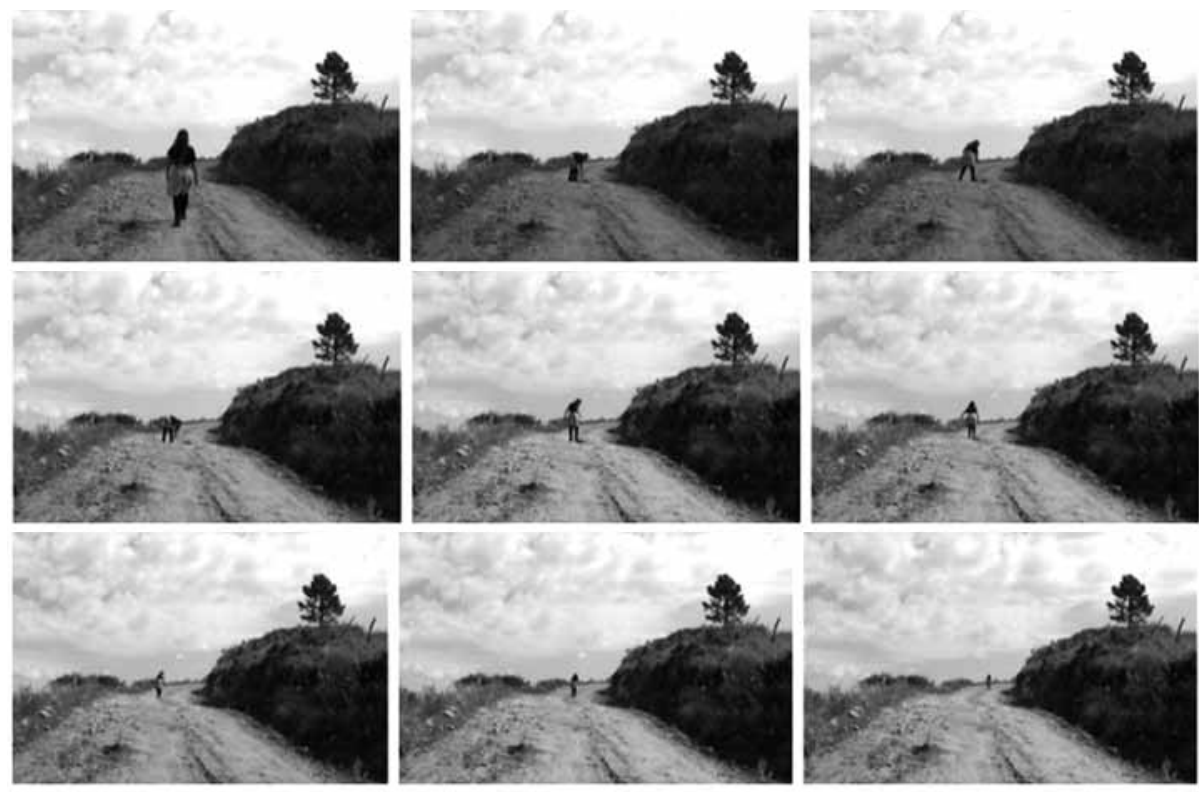

desvanece y solo hay espacio para la epifanía multimedial del conjunto.

Hay ahora una referencia de grupo colectivo audiovisual que aglutina y a la vez, focalizaciones individuales que atraen enmarcadas por la pantalla, donde irán apareciendo las partes de la estructura estratégica del anclaje visual y se logra un recorrido con mirada direccionada ineludible a partir del recurso dominante, del loop, reproducido incansablemente en la resolución de estas obras.

\section{Instalada en un tiempo contínuo}

Elegir un momento y no otro puede hacer la diferencia, en las obras de Cintia Romero es notoria esta intensión, aunque cualquier tramo seleccionado le daría los mismos beneficios para sus armados audiovisuales. Monta un fragmento en forma repetitiva, crea una obsesiva visión de ese instante, se aferra una y otra vez sobredimensionando el segundo elegido y de ese modo planta e impone una idea, nada mas y nada menos que la transformación de una reiteración en un posible avance, en un modo de situarse en el límite impuesto al tiempo.

No avanza ni retrocede, se instala allí, en un tiempo continuado en sí mismo, en un fijo y a la vez amplificado instante donde la reiteración sobre la acción, delimita una construcción, la continuidad está tomada como un acontecimiento 
trazado en la posibilidad incierta, es la instancia latente de lo futuro que finalmente se consolida como tramofragmento e inmediatamente deja de serlo para atender al completo y potente relato infatigable en la artista.

Cintia Romero se autoconvoca y se autorreferencia, es su centro visual y su clave de reflexión, cuando se corre de ese lugar genera y construye visualmente atendiendo a otros, desde sí misma. Sus procesos productivos son claros e insisten con la naturaleza como contexto de espacio contundente. Desde ese lugar amplio, profundo, sin límites y en evolución permanente, planta un quiebre, un impedimento, sin fatiga repite, reitera como haciendo un paréntesis en el devenir, marcando una conciliación con otro universo en espera, un cosmos en suspenso, tal vez para ver si puede crear otro mundo y modificar desde ese instante fijado, la naturaleza de las cosas y cuando continúa la trama, ver si otro es el estado de los acontecimientos.

La artista, desde ese enclave autónomo, arma la potencia vital de otra estructura en contrapartida a la conocida, volver a partir es destruir el orden establecido y la linealidad pautada del relato con su inicio, desarrollo, desenlace y final como lo conocemos.

La acción circular no permite determinar estos puntos, es más, Romero se abstiene de generarlos y se produce otra dialéctica con la trama de su relato. De este modo el fragmento avanza de alguna manera, progresa en su inquietante resultado y produce un nuevo marco de referencia para la percepción del que observa.

De alguna manera, ofrece resistencia para verificar que ese continuo luego, ha variado, allí está su límite, la certeza de saber que sigue andando anclada en los pliegues del tiempo, obstinada intentando liberarse con su accionar a cuestas produciendo un nuevo marco de referencia para la percepción del que observa.

Como en un mecanismo de autorregulación, intenta una y otra vez mantener presente a perpetuidad y demanda, aferrada como testigo del tiempo, la esperanza del logro en y piensa que algo es posible en su utopía. 